\title{
Epidemiology of Exobasidium Leaf and Fruit Spot of Rabbiteye Blueberry: Pathogen Overwintering, Primary Infection, and Disease Progression on Leaves and Fruit
}

\author{
R. J. Ingram, H. D. Ludwig, and H. Scherm ${ }^{\dagger}$ \\ Department of Plant Pathology, University of Georgia, Athens, GA
}

\begin{abstract}
Epidemiological field studies utilizing disease monitoring, spore trapping, and trap plants were conducted on rabbiteye blueberry (Vaccinium virgatum) between 2014 and 2017 to shed light on the epidemiology of Exobasidium leaf and fruit spot, an emerging disease in the southeastern United States caused by the fungus Exobasidium maculosum. Wash plating of field-collected blueberry tissue from the late dormant season through bud expansion showed that the pathogen overwintered epiphytically on blueberry plants in the field, most likely in its yeast-like conidial stage. Agrichemical applications during the dormant season altered epiphytic populations of the pathogen, which correlated directly with leaf spot incidence later in the spring. Disease monitoring of field plants and weekly exposure of potted trap plants revealed that young leaves at the mouse-ear stage were most susceptible to infection, that disease incidence on leaves progressed monocyclically, and that infection periods were associated with rainfall variables such as the number of days per week with $\geq 1.0 \mathrm{~mm}$ of rain or cumulative weekly rainfall. Weekly spore

trapping with an Andersen sampler showed that airborne inoculum was detected only after sporulating leaf lesions producing basidiospores were present in the field, suggesting that the primary inoculum is not airborne. The first symptoms on young, green fruit were observed soon after petal fall (requiring removal of the waxy fruit layer to visualize lesions), and visible disease progress on fruit was delayed by 1 to 3 weeks relative to that on leaves. Fruit infection of field plants and trap plants occurred before airborne propagules were detected by spore trapping and before sporulating leaf lesions were present in the field. Hence, this study showed that fruit infections are initiated by the same initial inoculum as leaf infections but it was not possible to conclusively exclude the possibility of a contribution of basidiospore inoculum from leaf lesions to disease progress on later developing fruit. This is one of only a few studies addressing the epidemiology and disease cycle of an Exobasidium sp. in a pathosystem where artificial inoculation has not been possible to date.
\end{abstract}

During the past decade, Exobasidium leaf and fruit spot of blueberry has emerged from a curiosity to a serious disease causing economic losses. The first reports of a spot disease in blueberry caused by an Exobasidium sp. were from unmanaged and managed wild lowbush blueberry (Vaccinium angustifolium Aiton) fields in Nova Scotia (Canada) in 1997 and subsequently from commercial fields of northern highbush blueberry (V. corymbosum L.) in North Carolina in 1998 (Cline 1998; Nickerson and Vander Kloet 1997). Noted in the report by Nickerson and Vander Kloet (1997) was the sporadic occurrence of whitish to pale-green spots on the leaves of mostly shaded lowbush blueberry plants, whereas Cline (1998) observed morphologically similar spot symptoms on both leaves and fruit of infected northern highbush plants. Both reports, although different in symptomology and host species, attributed the disease to an Exobasidium sp. within the Exobasidium vaccinii species complex. During the past decade, Exobasidium leaf and fruit spot has become particularly prevalent and severe in blueberry-producing regions of the southeastern United States on rabbiteye ( $V$. virgatum Aiton) and, to a lesser extent, southern highbush (V. corymbosum interspecific hybrids) cultivars (Brannen et al. 2011). Recent phylogenetic analysis has revealed that the causal organism of the disease is a previously undescribed species, E. maculosum M. T. Brewer (Brewer et al. 2014). Although members of the same species, populations of E. maculosum from rabbiteye and highbush blueberry in the

${ }^{\dagger}$ Corresponding author: H. Scherm; E-mail: scherm@uga.edu

Funding: Funded by the Georgia Agricultural Commodity Commission for Blueberries and USDA-NIFA CARE award number 2015-67028-23541.

The author(s) declare no conflict of interest.

Accepted for publication 24 January 2019.

@ 2019 The American Phytopathological Society southeastern United States are distinct from those on lowbush blueberry in the northeastern United States and Canada (Stewart et al. 2015). E. maculosum is distinct from the Exobasidium sp. (previously referred to as E. vaccinii (Fuckel) Woronin) causing red leaf disease of lowbush blueberry (Brewer et al. 2014).

A detailed description of the symptomology of Exobasidium leaf and fruit spot of rabbiteye blueberry is presented in Ingram et al. (2017). Commercial crop losses are mainly associated with the fruit-spotting phase of the disease; the green spots fail to ripen, rendering the berry fruit unmarketable and increasing sorting costs in the packinghouse due to the difficulty of removing infected fruit. In addition to leaf and fruit spots, the pathogen can also cause necrotic, girdling lesions on young shoots, which further contribute to yield losses via the reduction of fruiting wood (Ingram et al. 2017). Although formal crop loss estimates are currently lacking, Cline (1998) reports fruit losses of $25 \%$ in a severely affected field of northern highbush blueberry in North Carolina.

Information about the epidemiology of diseases caused by Exobasidium spp. in general, and of Exobasidium leaf and fruit spot of blueberry in particular, is limited (Cline and Brewer 2017). Leaf symptoms appear early in the growing season (late March to early April in the southeastern United States), suggesting that young, emerging leaves are infected (Ingram et al. 2017). By early summer, a distinct red margin forms around leaf and shoot spots as they become brown to black, necrotic, and occasionally form shot holes. No new disease symptoms are observed on young leaves that emerge during summer and fall. Fruit symptoms are readily apparent in the field in early summer when the berry fruit turn color; however, closer inspection reveals symptoms on green fruit as early as 2 weeks after petal fall, especially when the waxy layer of the fruit is removed (e.g., with ethanol) (Ingram et al. 2017). The types of inocula causing leaf and fruit spots and the mode of oversummering and overwintering of the pathogen are currently unknown (Cline and Brewer 2017). The disease is controlled readily with a single, late-dormant application of liquid lime sulfur (Brannen et al. 2017), a primarily surface-active fungicide, suggesting that the pathogen may overwinter epiphytically on blueberry tissues in the field. 
E. maculosum produces two spore types: two-celled basidiospores and single-celled yeast-like conidia (Brewer et al. 2014). Basidiospores are formed on basidia that are part of a thin hymenial layer on the lower surface of leaves as well as on fruit and stem spots, whereas the conidia are produced by budding at each end of basidiospores. When basidiospores or conidia are plated on culture media, the pathogen grows as a yeast colony, whereas filamentous (hyphal) growth is observed only in infected plant tissue. The roles of the two spore types in the disease cycle of Exobasidium leaf and fruit spot are unclear but there is some information available from other Exobasidium pathosystems. Some species (such as the Exobasidium sp. causing red leaf of lowbush blueberry) incite systemic infections in their hosts following basidiospore infection of young stems (Mims and Nickerson 1986; Nickerson and Hildebrand 2017; Nickerson and MacNeill 1987), whereas others (such as E. vexans Massee causing blister blight of tea) produce polycyclic leaf spot epidemics via repeated cycles of basidiospore dispersal and infection (Gadd and Loos 1948). In other examples, such as E. japonicum Shirai causing leaf galls on azalea, both basidiospores and conidia are capable of infecting young, emerging leaves following dormant bud inoculation (Graafland 1960). The wide range of life histories of Exobasidium diseases warrants closer investigation of the disease cycle specific to E. maculosum. It is important to note that, outside of the systemic in planta mycelial overwintering of the Exobasidium sp. causing red leaf of lowbush blueberry, to the best of the authors' knowledge, no study has been able to clearly evidence and identify the mode of overwintering and, therefore, provide a complete disease cycle for any disease caused by this group of phytopathogens.

Artificial inoculation experiments using basidiospores or conidia of several Exobasidium sp. have produced infections on typically young and tender host plant tissues (Graafland 1960). For example, Nickerson and Vander Kloet (1997) reported reproducing leaf spot symptoms on lowbush blueberry ( $V$. angustifolium) by artificial inoculation with conidia of $E$. maculosum. In contrast, artificial inoculation of young leaves or fruit of rabbiteye blueberry with basidiospores or conidia of diverse isolates (and combinations of isolates) of E. maculosum by different lab groups has not resulted in successful infection (M. T. Brewer, unpublished; H. Scherm, unpublished). Hence, it is currently not possible to shed light on the disease cycle of Exobasidium leaf and fruit spot via artificial inoculation experiments. Based on these considerations, we report here the results of epidemiological field studies to unravel the means of pathogen overwintering, spore dispersal, seasonal timing of infection, and disease progression in the Exobasidium leaf and fruit spot pathosystem on rabbiteye blueberry. Preliminary results have been published in a proceedings report (Ingram et al. 2017).

\section{Materials and Methods}

Field site and plant material. The experiments reported below were conducted between 2014 and 2017 in a commercial rabbiteye blueberry planting with a history of Exobasidium leaf and fruit spot near Alma, GA. The planting consisted of alternating rows of three cultivars (Premier, Climax, and Tifblue) but only Premier, which is highly susceptible to Exobasidium leaf and fruit spot, was used in the study. Plants were mature (>20 years old in 2014) and were left untreated with fungicide throughout the study period (except for the 2017 trial, in which agrichemical applications were used to manipulate overwintering surface inoculum densities). All other horticultural and pest management practices followed those recommended for commercial rabbiteye blueberry production in the southeastern United States (Burrack 2013).

Quantification of dormant-season surface populations. Tissue samples were collected from one or more rows of Premier plants located near the eastern woodline of the planting during the dormant seasons (January or February) and during leaf and flower bud expansion (March) in 2014, 2015, and 2016 to determine presence and levels of epiphytic populations of E. maculosum by wash plating. Tissue types tested were leaf buds (from dormant to mouse-ear); flower buds (from dormant through full bloom); green bark from the previous year's growth; and mature, woody bark from growth that was 2 years old or older (included in 2014 only). Sampling was conducted weekly by collecting the distal 10 - to 20 -cm segments of the previous year's shoots (fruitwood) by removing 2 shoots from both sides of a bush, then skipping a bush, and continuing until a total of 40 shoots had been obtained. Shoot segments were shipped overnight or brought directly to Athens, GA, where they were stored at $4{ }^{\circ} \mathrm{C}$ and processed within 5 days of collection. In all, 20 shoot segments were selected randomly and 2 segments were combined to give 10 experimental units. Using a sterile scalpel, eight leaf buds and eight flower buds were removed from each set of two shoots. Bark (10 mg), excluding tissue beneath the bark, was removed using a sterile scalpel. After excision, weights of all tissue samples were recorded and each tissue type was placed in a $1.5-\mathrm{ml}$ microcentrifuge tube prefilled with $1 \mathrm{ml}$ of $0.01 \%$ Tween 80 in sterile distilled $\mathrm{H}_{2} \mathrm{O}$, with the steps repeated for each of the 10 experimental units. At the point in the growing season when flower and leaf buds on collected shoots had broken and reached full bloom and shoot elongation, the volume of the wash solution for these two tissue types was doubled from 1 to $2 \mathrm{ml}$ within a 10-ml tube. All tubes with tissue samples were sonicated in a water bath for 2 min (Branson 2000; Branson Ultrasonics Corp., Danbury, CT, U.S.A.) and then vortexed for $30 \mathrm{~s}$ immediately before wash plating $0.1 \mathrm{ml}$ of tissue wash suspension onto the semiselective medium M5 (Ingram et al. 2017) in quadruplicate for each of the 10 tissue-specific experimental units. Aliquots of the tissue wash suspension were placed at $-80^{\circ} \mathrm{C}$ for later molecular confirmation of the accuracy of the visual identification of E. maculosum colonies. Petri dishes were placed in a plastic crisper box at 21 to $23^{\circ} \mathrm{C}$ and 70 to $75 \%$ relative humidity for 2 weeks, at which time each dish was reviewed under a dissection microscope $(\times 60)$ for characteristic E. maculosum colonies (cream to pink, raised, farinose, and with an irregular margin) (Ingram et al. 2017). Colony counts were recorded along with the initial weight of tissue placed in each microcentrifuge tube to calculate the number of CFU of E. maculosum per gram of tissue for each tissue type and sampling date.

For molecular confirmation, previously frozen wash-plating aliquots were spread plated onto M5 medium, and representative colonies $(n=35)$ visually identified as E. maculosum were subcultured on potato dextrose agar amended with streptomycin at $50 \mathrm{mg} /$ liter. Yeast conidial suspensions from these colonies were confirmed by realtime polymerase chain reaction (PCR), as described by Ingram (2018). Briefly, genomic DNA was extracted by beat beating a yeast conidial suspension (standard concentration adjusted to an optical density of 0.10 to 0.12 in $0.01 \%$ Tween 80 ) using two 40 -s FastPrep cycles in a Mini-Beadbeater-1 (BioSpec Products, Bartlesville, OK, U.S.A.). Each PCR reaction included $5 \mu l$ of DNA extract (approximately $15 \mathrm{ng} / \mu \mathrm{l}), 10 \mu \mathrm{l}$ of Luna Universal Probe qPCR Master Mix (New England Biolabs, Ipswich, MA, U.S.A.), $0.8 \mu l$ of primer EXORI-F (forward-5' CTC TTC CTC TAC ATT CTT 3'), $0.8 \mu l$ of primer EXORI-R (reverse-3' CAC ATT ACT TAT CGC ATT 5'), $0.4 \mu \mathrm{l}$ of probe EXORJI $\left(10 \mu \mathrm{M} ; 5^{\prime}\right.$ agt Tcg Ctc Agt Ggc acc t $\left.3^{\prime}\right)$ with a $5^{\prime}$ 6-FAM fluorescent reporter dye and $3^{\prime}$ Iowa BlackFQ quencher (Integrated DNA Technologies, Coralville, IA, U.S.A.), and $3 \mu \mathrm{l}$ of double-distilled (dd) $\mathrm{H}_{2} \mathrm{O}$ in an Applied Biosystems 0.1-ml MicroAmp Fast 96-well Reaction Plate (ThermoFisher Scientific, Waltham, MA, U.S.A.) and sealed with MicroAmp TriFlex $3 \times$ 32-Well PCR Reaction Plate Clear Adhesive Film. Cycle conditions in the Applied BioSystems StepOnePlus Real-Time PCR System (ThermoFisher Scientific) were $95^{\circ} \mathrm{C}$ for $2 \mathrm{~min}$ followed by cycling between $95^{\circ} \mathrm{C}$ for $15 \mathrm{~s}$ and $50^{\circ} \mathrm{C}$ for $30 \mathrm{~s}$ up to a cycle threshold $(\mathrm{Ct}$ value) of 45 . The settings in the thermocycler software were altered for TaqMan polymerase, reporting by a TaqMan fluorescent probe, and set to fast run, whereas the $\mathrm{Ct}$ value and all other settings were left at the default. All samples were run in triplicate using DNA of E. maculosum isolate EXOA as a positive control and $\mathrm{dd}_{2} \mathrm{O}$ as a negative control.

Leaf spot development in the field. The study was conducted during the 2015, 2016, and 2017 growing seasons but the 2017 trial had to be discontinued after a late freeze in mid-March damaged leaf tissue and flowers, resulting in an insufficient fruit crop (Collins 2017). At the mouse-ear stage of leaf bud development (NeSmith 
et al. 1998) in early March of each year, 72 newly emerged shoots on plants within a row were flagged, with four shoots on each side of every other bush from 1 to $2 \mathrm{~m}$ high tagged at random. These shoots were monitored weekly from late February until June for the occurrence of Exobasidium leaf spots on all leaves within a shoot $(n=4$ to 15 leaves per fully expanded shoot).

At each assessment date, leaf spots were classified based on their stage of development (Ingram et al. 2017). New spots were small (1 to $2 \mathrm{~mm}$ ) and chlorotic without a light yellow halo. Mature spots were yellow on the upper surface of the leaf with a green-yellow halo and a white underside but no visually apparent sporulation. Sporulating spots were yellow on the upper surface of the leaf with or without a green-yellow halo and a velvety-white underside. Postsporulating spots were yellow or brown on the upper surface and gray, brown, or black on the underside of the leaf, occasionally associated with a distinct red margin. Disease progress was plotted for the four leaf spot classes based on the average number of leaf spots per shoot for each assessment date.

Fruit spot development in the field. Starting at petal fall in late March or early April and ending at 40 to $50 \%$ ripe fruit in late May or early June in 2015 and 2016, between 32 and 36 fruit clusters were sampled from four field plants within the experimental row by removing four fruit clusters from both sides of every other bush starting at the third bush. This resulted in 93 to 240 fruit per sampling date. Fruit samples were immediately brought into the lab, placed in $4{ }^{\circ} \mathrm{C}$, and assessed for fruit spot incidence within 1 week of sampling. All fruit was sprayed with $10 \%$ ethanol to remove the waxy surface layer that would otherwise obscure disease spots on green fruit. This effect was only present when the surface of green fruit was still wet with the ethanol spray. Disease progress was plotted based on fruit disease incidence data.

Early-season airborne spore sampling. From late February to late May or early June in 2015 and 2016, weekly sampling for airborne E. maculosum spores was conducted using a batteryoperated six-stage viable Andersen sampler (Air Quality Instruments, Franklin, MA, U.S.A.). The sampler was placed within the plant row between two bushes, $1.0 \mathrm{~m}$ above the ground, fitted with six Petri dishes containing the semiselective M5 medium (Ingram et al. 2017), and operated for two separate time periods (30 and $60 \mathrm{~s}$ ) at midnight on the same day of the week each week. Considering the two run times and the sampler's air suction rate of 28.3 liters/ min, the detection threshold was calculated as 24 propagules $/ \mathrm{cm}^{3}$ of air. After the two exposure periods, Petri dishes were placed in a plastic sleeve and brought to the lab the next day. To allow for colony development, dishes were placed in a partially opened plastic crisper box for 2 weeks $\left(21\right.$ to $23^{\circ} \mathrm{C}, 70$ to $75 \%$ relative humidity). For each sampling date, the sampler run time having countable numbers of E. maculosum colonies was selected, and colony counts on all stages corresponding to that run time were taken and converted to CFU per minute. Because exact counts were not always possible due to the presence of other fungal colonies, each sampling date was classified for aerial propagule numbers on a semiquantitative scale as absent (0 CFU), low (1 to $50 \mathrm{CFU}$ ), medium (51 to 200 $\mathrm{CFU})$, and high (>200 CFU).

Identification of primary leaf and fruit infection periods using trap plants. Two-year-old potted plants of Premier, obtained from Bottoms Nursery (Concord, GA, U.S.A.) and maintained for different periods in a cold room and greenhouse to obtain susceptible leaf or fruit stages, were used as trap plants by exposing them to natural inoculum in the aforementioned rabbiteye blueberry planting for weekly intervals during the epidemic in 2015 and 2016. Target stages at the time of field exposure were mouse-ear to early shoot elongation for leaves (NeSmith et al. 1998) and 0.25- to 0.75-cm green fruit diameter for fruit. Because of the different timing of these phenological stages for leaves and fruit on the same plant, separate groups of trap plants were required to monitor leaf and fruit infection. Plants were manipulated to maintain dormancy prior to use by storing them in darkness in a walk-in cold room at 5 to $8^{\circ} \mathrm{C}$. At 2 to 3 weeks prior to placement in the field for leaf trap plants and 5 to 7 weeks for fruit trap plants, plants were moved from the cold-room into the greenhouse $\left(22\right.$ to $28^{\circ} \mathrm{C}, 12 \mathrm{~h}$ of light). Bumblebees (Koppert Natupol Class C hive; Koppert Biological Systems, Howell, MI, U.S.A.) were used to pollinate fruit trap plants over a period of 2 weeks by placing two hives within a section of greenhouse containing Premier trap plants and pollinator plants Alapaha and Climax at full bloom.

Leaf trap plants (four or five per week) with the appropriate leaf development stages were exposed weekly from late February to late May in 2015 and 2016. Similarly, fruit trap plants (four per week) were exposed weekly between early March and mid-May 2016. Trap plants were placed in the field in pot-depth holes located between field blueberry plants within a single row and were left in the field for an exposure period of 7 days. Starting in late April, when temperatures began to exceed $27^{\circ} \mathrm{C}$, trap plants were prevented from drying out with a custom-made drip watering system. At the end of each exposure period, trap plants were brought back into the greenhouse and placed under a shade cloth on a mist bench (misting rate: $10 \mathrm{~s}$ every $1 \mathrm{~h}$ ). After 1 week, plants were moved to a separate section of the greenhouse and then monitored for symptom development (number of leaf or fruit spots per plant) once a week for 1 month. Trap plants with phenology similar to those exposed in the field at each exposure interval were retained in the greenhouse to serve as controls.

Correlation analysis was used to relate the average number of leaf spots per trap plant during weekly exposure periods from mid-March to mid-May in 2015 and 2016 ( $n=10$ each year) with select rainfall variables (i.e., the number of days per week with $\geq 1.0 \mathrm{~mm}$ of rain and cumulative weekly rainfall as recorded with a standard agricultural weather station located approximately $3 \mathrm{~km}$ from the experimental site).

Susceptibility of leaf stages. The trap plant studies described above were used to determine the susceptibility of different leaf development stages to primary infection by E. maculosum. In one set of experiments in 2016, two fruit trap plants having more advanced leaf development stages were used to test the susceptibility of tender leaves versus those that had already hardened-off. These plants had 15 shoots/plant flagged at the junction of hardened-off (proximal) and tender (distal) leaves. In a separate set of experiments using leaf trap plants from February to mid-May in 2015 and 2016, a total of five shoots per leaf development stage (NeSmith et al. 1998) per plant were flagged to assess the relative susceptibility of stages 3 (green tip), 4 (mouse ear), and 5 (shoot elongation) to infection by E. maculosum. At the end of each weekly exposure period, plants were returned to the greenhouse, placed under a shade cloth on a mist bench, and assessed for Exobasidium leaf spots, as described previously. A $\chi^{2}$ contingency table analysis was used to determine associations between leaf development stages and the presence or absence of symptoms on leaves.

Chemical-based manipulation of dormant-season surface populations of $\boldsymbol{E}$. maculosum and impact on primary infection. This study was conducted on field plants of Premier rabbiteye blueberry in Alma, GA, during the 2017 growing season. At the late-dormant stage of development, a fungicide trial was conducted to assess the impact of reduced or increased surface population levels of E. maculosum on the incidence of Exobasidium leaf spot in the field. Treatments included an untreated control, lime sulfur (18.7 liters/ha in 467.6 liters/ha water; Lime Sulfur Ultra; OrCal, Junction City, OR, U.S.A.), and two horticultural products: hydrogen cyanamide (7.0 liters/ha in 467.6 liters/ha water; Dormex; AlzChem, Trostberg, Germany) and mineral oil (28.2 liters/ha in 935.2 liters/ha of water; Damoil; Drexel, Memphis, TN, U.SA.). Previous research had shown that dormant applications of lime sulfur and hydrogen cyanamide decrease disease incidence, whereas dormant oil applied at the same time increased the disease (Scherm et al. 2017), and we hypothesized that this was the case because of an impact of these products on overwintering surface populations of E. maculosum. Applications were made on 18 January at the late-dormant stage of plant development using an air-blast sprayer set to $413.7 \mathrm{kPa}$ and fitted with standard cone nozzles. The experiment was designed as a randomized complete block with four replications of four-bush plots within a single row, with two untreated bushes between treatments and an untreated buffer row on either side. 
To quantify surface population levels of E. maculosum, shoot samples were collected from each plot 1 day prior to application, 2 days after application, 8 days after application, and 59 days after application. In all, 5 shoots (10 to $20 \mathrm{~cm}$ in length) were excised from both sides of each bush within a plot for a total of 20 shoots/plot. Shoot samples were shipped overnight from Alma to Athens and all samples were processed as described previously, with the only exception being that only green bark was tested in this study.

On 15 May, 20 current-season shoots per plot were collected and assessed for shoot-level incidence of Exobasidium leaf spot by calculating the percentage of shoots with a least one infected leaf. Treatment means were calculated and regressed against log-transformed E. maculosum population densities (CFU) determined for the same treatments at the 59-day posttreatment sampling in mid-March $(n=4)$. No fruit spot assessments were possible in 2017 due to a total crop loss following the mid-March freeze.

\section{Results}

Quantification of dormant-season surface populations. Epiphytic populations of E. maculosum (in its yeast stage on culture media) were consistently recovered by wash plating from blueberry tissues sampled between the beginning of February and late March at the experimental site (Fig. 1). Population densities were variable, ranging from $<10$ to $>10^{4} \mathrm{CFU} / \mathrm{g}$ of fresh tissue; the lowest densities were generally observed on leaf and flower buds later during the sampling period (late February and beyond), presumably because of a dilution effect as leaf and flower tissues expanded rapidly following

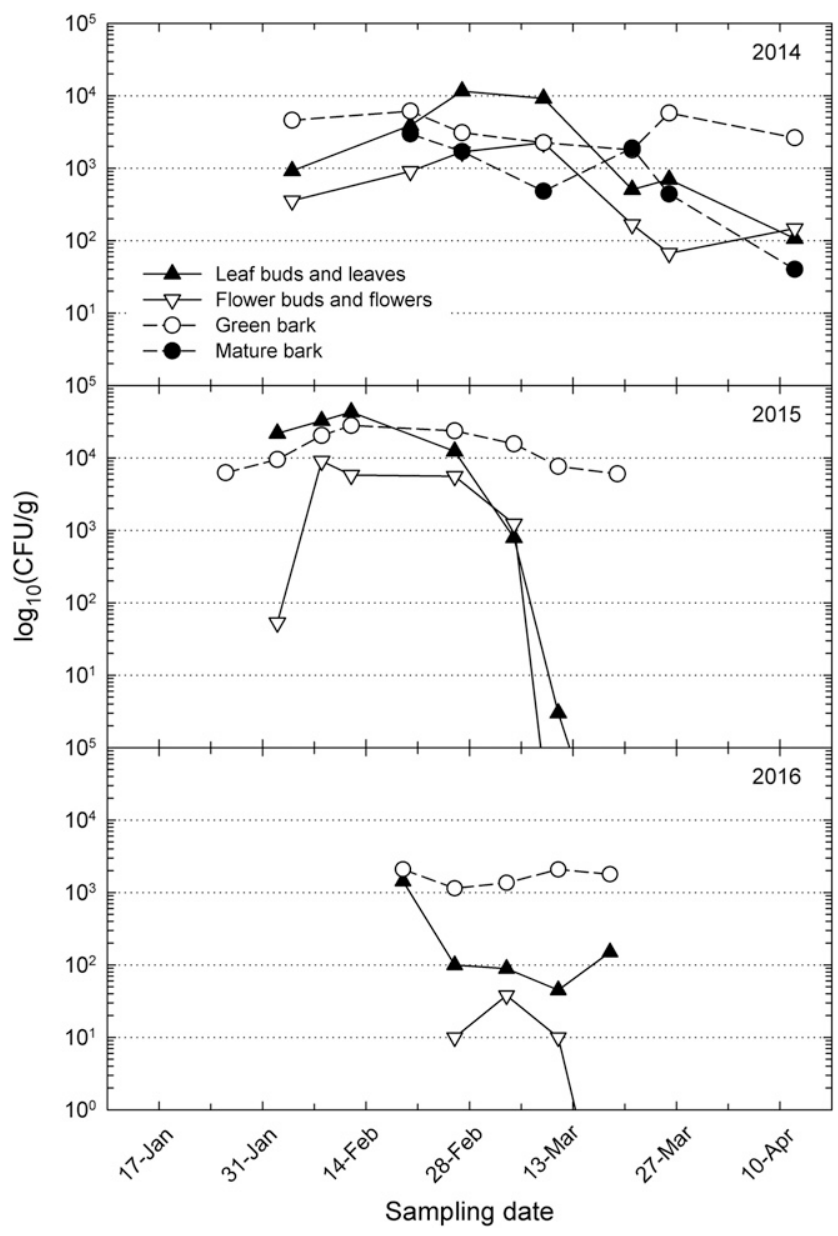

Fig. 1. Epiphytic population densities of Exobasidium maculosum, determined by dilution plating onto semiselective medium, on different tissues of field-grown Premier rabbiteye blueberry plants during winter and early spring of 2014 to 2016. Values are means of 10 experimental units, each obtained by pooling tissue samples obtained from two shoots. No colonies of $E$. maculosum were recovered from mature bark on the first sampling date in 2014. bud break. Consistently high numbers $\left(>10^{3} \mathrm{CFU} / \mathrm{g}\right)$ were recovered from green bark throughout the sampling period (Fig. 1), whereas numbers on mature bark (included only in 2014) were more variable; no colonies of $E$. maculosum were recovered from mature bark tissue during the first sampling date in 2014.

Of 35 colonies identified morphologically as being characteristic of E. maculosum, 33 of the samples were confirmed as such by real-time PCR. The two negative colonies were reevaluated by amplifying their 5.8s internal transcribed spacer (ITS) regions by conventional PCR using the universal fungal primers ITS1-F and ITS4; a BLAST search of the sequenced amplicons revealed that these colonies were E. maculosum as well (identity $=99 \%$ ), suggesting that they were false negatives in the real-time PCR. Thus, visual assessment based on colony morphology was highly accurate in identifying the fungus from tissue wash platings.

Leaf and fruit spot development in the field. The first leaf spots on field plants appeared during the period of shoot expansion in late March to early April in both 2015 and 2016 (Fig. 2). Subsequent disease progression on leaves followed that of a monocyclic disease, as suggested by single peaks for the four leaf spot classes (new, mature, sporulating, and postsporulation). The first sporulating leaf spots (with visible presence of basidiospores) were observed in early to mid-April, and this class made up the majority of all leaf spot classes between late April and mid-May. Thereafter, spots became necrotic, no longer supporting visible sporulation. The decrease in the average number of leaf spots per shoot from May onward (Fig. 2) was due to defoliation of severely affected leaves (Ingram et al. 2017).

Progression of fruit disease incidence was similar across the 2 years (Fig. 2). The first spots on green fruit were observed in early to mid-April, 1 to 3 weeks after the first observation of spots on leaves. Subsequently, fruit spot incidence increased to peak in early May, followed by a decrease in the proportion of symptomatic fruit prior to harvest, most likely due to premature drop of affected fruit (Ingram et al. 2017).

Early-season airborne spore sampling. Data collected with the Andersen sampler produced semiquantitative information on the relative abundance of airborne propagules (presumably basidiospores) of E. maculosum during specific weekly sampling periods (Tables 1 and 2). No airborne spores were detected prior to or during the emergence of the first new leaf spots on field plants. The first presence of airborne spores was recorded after the appearance of sporulating leaf spots in the field, and the highest spore densities generally were associated with those periods when sporulating spots made up the majority of the four leaf spot classes (Tables 1 and 2; Fig. 2).

The first fruit spots on field plants occurred 1 week after airborne propagules were first detected with the Andersen sampler in 2015, whereas fruit spot detection preceded spore detection by 2 weeks in 2016 (Tables 1 and 2). Airborne spores were still detected at the end of the sampling period in late May or early June, after the number of sporulating leaf spots on field plants had declined sharply.

Identification of primary leaf and fruit infection periods using trap plants. Infection of potted trap plants during weekly exposure periods occurred 1 or 2 weeks prior to the appearance of the first leaf spots in the field (Tables 1 and 2); hence, assuming an incubation period of approximately 1 to 2 weeks in the field, this suggests that leaves on field plants and trap plants were infected by the same initial inoculum. Across the 2 years, the highest levels of leaf infection on trap plants were generally noted between late March and mid-April, although there was some week-to-week variation. Considerable leaf infection occurred in both years prior to the presence of sporulating leaf spots on field plants and prior to the detection of airborne propagules with the Andersen sampler (Tables 1 and 2). Conversely, no additional leaf infection on trap plants occurred from early May onward, despite the presence of high numbers of airborne E. maculosum spores as recorded by the Andersen sampler during that period. No symptoms of Exobasidium leaf spot occurred on control trap plants (not placed in the field) in either year.

In both years, the average number of leaf spots per trap plant during weekly exposure periods from mid-March to mid-May correlated positively with rainfall variables summarized for the same 

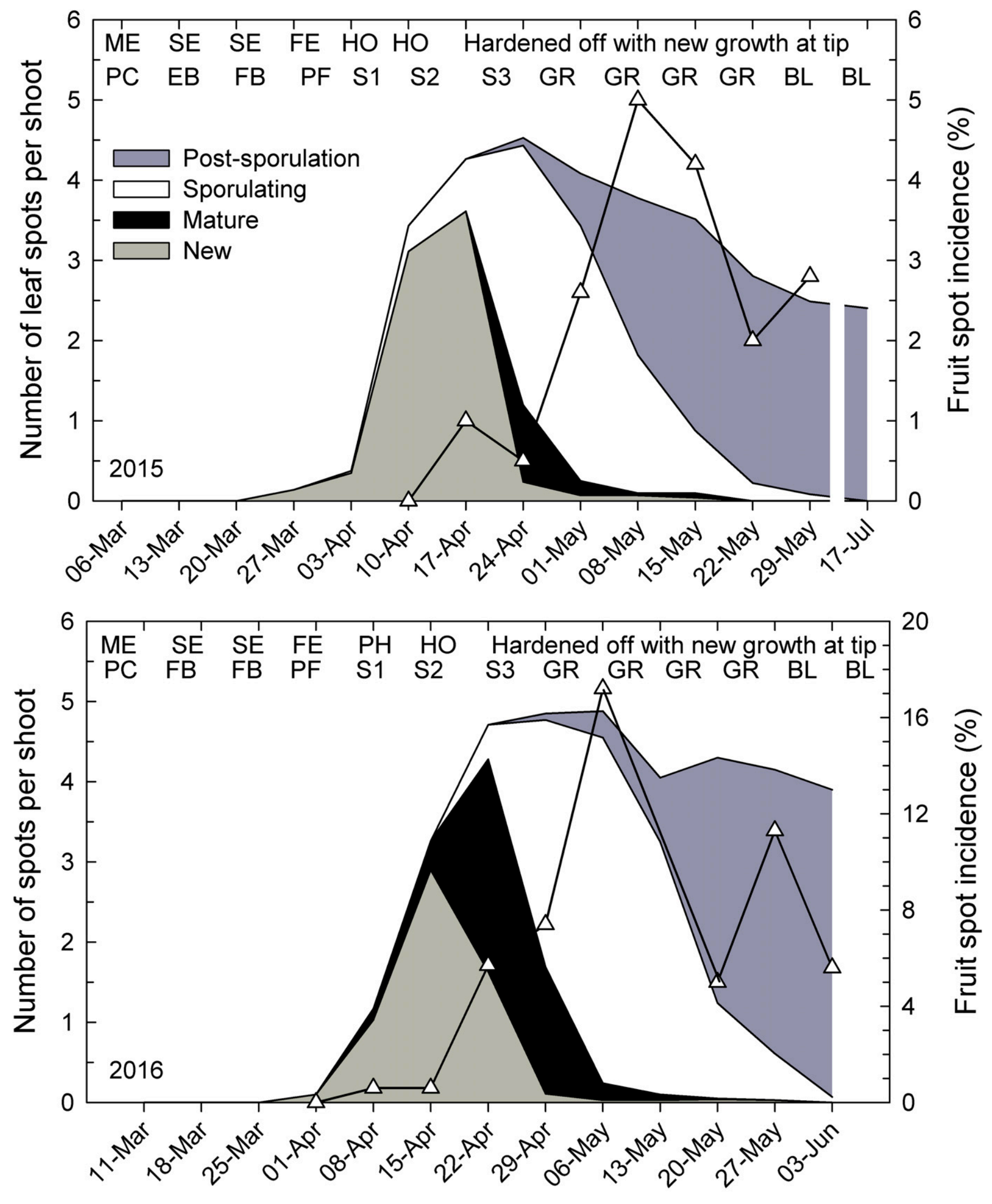

\section{Assessment date}

Fig. 2. Progress of Exobasidium leaf spot (stacked curves) and fruit spot (open triangles) on current-season shoots of field-grown Premier rabbiteye blueberry plants during spring and early summer 2015 (top) and 2016 (bottom). At each assessment date, the relative proportion of presporulating (new or mature), sporulating, and postsporulating (necrotic) leaf lesions is presented. Values are means of 72 shoots per assessment date for leaf spot progression and 93 to 240 fruit per date for fruit spot progression. For each assessment date, the most common leaf development stages are indicated at the top of each graph as follows: $\mathrm{ME}=$ mouse ear, $\mathrm{SE}=$ shoot expansion, $\mathrm{FE}=$ fully expanded shoot with basal leaves unfurled, $\mathrm{PH}=$ basal leaves on shoot hardened off, and $\mathrm{HO}=$ all leaves on shoot hardened off. Similarly, the most common flower development stages are indicated as $\mathrm{PC}=$ pink corolla, $\mathrm{FB}=$ full bloom, $\mathrm{PF}=$ petal fall, $\mathrm{S} 1=$ small green fruit 0.25 to $0.50 \mathrm{~cm}$ in diameter, $\mathrm{S} 2=0.50$ to $0.75 \mathrm{~cm}, \mathrm{~S} 3=\geq 1.0 \mathrm{~cm}, \mathrm{GR}=$ fully expanded green fruit, and $\mathrm{BL}=$ blue fruit. 
week; that is, the number of days per week with $\geq 1.0 \mathrm{~mm}$ of rain in $2015(r=0.755, P=0.0116)$ and cumulative weekly rainfall in 2016 $(r=0.761, P=0.0106)$.

Fruit infection on trap plants was investigated only in 2016 (Table 2). Potted plants conditioned in the greenhouse to have early fruit development stages (green fruit 0.25 to $0.75 \mathrm{~cm}$ in diameter) were exposed in the field weekly between 4 March and 20 May 2016. Only relatively young, green fruit $<0.5 \mathrm{~cm}$ in diameter at the time of exposure became infected (data not shown). Overall fruit spot incidence was low during exposure periods resulting in infection, ranging from 0.75 to 2 affected fruit per plant (Table 2). The first fruit infection occurred on plants exposed during the week ending 25 March, which also corresponded to the first period of leaf infection on the separate batch of trap plants used to monitor leaf infection. The last fruit infection on trap plants occurred during the exposure period ending 15 April, which was prior to the appearance of sporulating leaf lesion on field plants and prior to the detection of airborne propagules with the Andersen sampler (Table 2). No additional fruit infection on trap plants occurred from late April onward, despite the presence of high numbers of sporulating leaf lesions on field plants and of the consistent presence of airborne E. maculosum propagules as recorded by the Andersen sampler during that period. No symptoms of Exobasidium fruit spot occurred on control trap plants (not placed in the field).
Susceptibility of leaf stages. On fruit trap plants where tender (distal) and hardened-off (proximal) shoot sections were tagged and monitored over time, leaf infection was significantly more likely on tender sections than on hardened-off sections on the same shoot $\left(\chi^{2}=51.1, P<0.0001, \mathrm{df}=1\right.$; Table 3$)$. When specific leaf development stages were tagged prior to exposure of leaf trap plants, leaf stages from late green tip to shoot elongation were found susceptible to infection, whereby those at the shoot elongation stage were most likely to be infected $\left(\chi^{2}=36.5, P<0.0001, \mathrm{df}=2\right.$; Table 4$)$.

Chemical-based manipulation of dormant-season surface populations and impact on primary infection. One day prior to the application of the dormant spray treatments, average epiphytic population densities of E. maculosum on green bark were similar across the four treatments, ranging from 2.1 to $4.4 \times 10^{3} \mathrm{CFU} / \mathrm{g}$ of tissue (Fig. 3). At 2 and 8 days after application, population densities declined for lime sulfur, remained relatively constant for hydrogen cyanamide, and increased for dormant oil and the untreated control (up to approximately $1.5 \times 10^{4} \mathrm{CFU} / \mathrm{g}$ ). At the last sampling date 59 days after treatment (in mid-March, when primary infection would be expected to occur based on disease progress data obtained in the previous 2 years), pathogen populations were highest for dormant oil, lowest for lime sulfur, and intermediate for hydrogen cyanamide and the untreated control (Fig. 3). Although Exobasidium leaf

Table 1. Progress of Exobasidium leaf spot on Premier field plants, presence of airborne spores, infection of Premier trap plants, and weekly temperature and precipitation in a blueberry planting near Alma, GA, in 2015

\begin{tabular}{|c|c|c|c|c|c|c|c|c|c|c|c|c|c|c|c|}
\hline \multirow[b]{2}{*}{ Variable } & \multicolumn{15}{|c|}{ Date $^{\mathbf{a}}$} \\
\hline & $\begin{array}{c}27 \\
\text { Feb }\end{array}$ & $\begin{array}{c}6 \\
\text { Mar }\end{array}$ & $\begin{array}{c}13 \\
\text { Mar }\end{array}$ & $\begin{array}{c}20 \\
\text { Mar }\end{array}$ & $\begin{array}{c}27 \\
\text { Mar }\end{array}$ & $\begin{array}{c}3 \\
\text { Apr }\end{array}$ & $\begin{array}{c}10 \\
\text { Apr }\end{array}$ & $\begin{array}{c}17 \\
\text { Apr }\end{array}$ & $\begin{array}{c}24 \\
\text { Apr }\end{array}$ & $\begin{array}{c}1 \\
\text { May }\end{array}$ & $\begin{array}{c}8 \\
\text { May }\end{array}$ & $\begin{array}{c}15 \\
\text { May }\end{array}$ & $\begin{array}{c}22 \\
\text { May }\end{array}$ & $\begin{array}{c}29 \\
\text { May }\end{array}$ & $\begin{array}{l}17 \\
\text { Jul }\end{array}$ \\
\hline Day of year & 58 & 65 & 72 & 79 & 86 & 93 & 100 & 107 & 114 & 121 & 128 & 135 & 142 & 149 & 198 \\
\hline New spots per shoot on field plants & 0 & 0 & 0 & 0 & 0.14 & 0.35 & 3.11 & 3.61 & 0.24 & 0.07 & 0.07 & 0.04 & 0 & 0 & 0 \\
\hline $\begin{array}{l}\text { Sporulating spots per shoot on } \\
\text { field plants }\end{array}$ & 0 & 0 & 0 & 0 & 0 & 0.03 & 0.32 & 0.65 & 3.24 & 3.18 & 1.72 & 0.78 & 0.22 & 0.08 & 0 \\
\hline Airborne spore density $(\mathrm{CFU} / \mathrm{min})^{\mathrm{b}}$ & A & A & A & A & A & A & $\mathrm{L}$ & M & M & $\mathrm{H}$ & $\mathrm{L}$ & $\mathrm{L}$ & $\mathrm{L}$ & $\mathrm{L}$ & ND \\
\hline Leaf spots per trap plant ${ }^{\mathrm{c}}$ & 0 & 0 & 0.25 & 52.5 & 207.3 & 1.00 & 0.25 & 145.5 & 0.25 & 0 & 0 & 0 & 0 & ND & ND \\
\hline $\begin{array}{l}\text { Days with } \geq 1.0 \mathrm{~mm} \text { of rain } \\
\text { per week }\end{array}$ & 2 & 2 & 2 & 3 & 4 & 0 & 0 & 5 & 2 & 3 & 0 & 0 & 2 & 2 & 2 \\
\hline Cumulative rainfall (mm per week) & 48.0 & 23.1 & 24.6 & 24.9 & 15.2 & 0.3 & 0.0 & 38.6 & 21.1 & 50.5 & 0.0 & 0.0 & 17.3 & 19.1 & 19.3 \\
\hline $\begin{array}{l}\text { Mean daily maximum } \\
\text { temperature }\left({ }^{\circ} \mathrm{C}\right)\end{array}$ & 14.6 & 19.6 & 22.8 & 24.6 & 22.8 & 22.3 & 28.4 & 26.2 & 26.0 & 24.5 & 26.6 & 31.6 & 31.9 & 30.4 & 35.0 \\
\hline
\end{tabular}

${ }^{a}$ Date denotes the end of the weekly exposure period for trap plants, the end of the weekly summary period for weather variables, and the weekly assessment date for disease variables and spore sampling.

${ }^{\mathrm{b}}$ Determined with a six-stage Andersen sampler operated separately for 30 and $60 \mathrm{~s}$ on each sampling date and categorized into four classes based on total number of Exobasidium maculosum CFU obtained in the sampler per minute: $\mathrm{A}=$ absent (0); $\mathrm{L}=$ low (1 to 50), $\mathrm{M}=$ medium $(51$ to 200$)$, and $\mathrm{H}=$ high $(>200) \mathrm{CFU} / \mathrm{min} . \mathrm{ND}=$ not determined.

${ }^{c}$ Average of four potted trap plants exposed weekly. ND = not determined.

Table 2. Progress of Exobasidium leaf spot on Premier field plants, presence of airborne spores, infection of Premier trap plants, and weekly temperature and precipitation in a blueberry planting near Alma, GA, in 2016

\begin{tabular}{|c|c|c|c|c|c|c|c|c|c|c|c|c|c|c|c|}
\hline \multirow[b]{2}{*}{ Variable } & \multicolumn{15}{|c|}{ Date $^{a}$} \\
\hline & $\begin{array}{c}26 \\
\text { Feb }\end{array}$ & $\begin{array}{c}4 \\
\text { Mar }\end{array}$ & $\begin{array}{c}11 \\
\text { Mar }\end{array}$ & $\begin{array}{c}18 \\
\text { Mar }\end{array}$ & $\begin{array}{c}25 \\
\text { Mar }\end{array}$ & $\begin{array}{c}1 \\
\text { Apr }\end{array}$ & $\begin{array}{c}8 \\
\text { Apr }\end{array}$ & $\begin{array}{c}15 \\
\text { Apr }\end{array}$ & $\begin{array}{c}22 \\
\text { Apr }\end{array}$ & $\begin{array}{c}29 \\
\text { Apr }\end{array}$ & $\begin{array}{c}6 \\
\text { May }\end{array}$ & $\begin{array}{c}13 \\
\text { May }\end{array}$ & $\begin{array}{c}20 \\
\text { May }\end{array}$ & $\begin{array}{c}27 \\
\text { May }\end{array}$ & $\begin{array}{c}3 \\
\text { Jun }\end{array}$ \\
\hline Day of year & 57 & 64 & 71 & 78 & 85 & 92 & 99 & 106 & 112 & 119 & 126 & 133 & 140 & 147 & 155 \\
\hline New spots per shoot on field plants & 0 & 0 & 0 & 0 & 0 & 0.10 & 1.03 & 2.90 & 1.63 & 0.11 & 0.03 & 0.03 & 0.04 & 0.03 & 0 \\
\hline $\begin{array}{l}\text { Sporulating spots per shoot on } \\
\text { field plants }\end{array}$ & 0 & 0 & 0 & 0 & 0 & 0 & 0 & 0 & 0.43 & 3.08 & 4.31 & 3.15 & 1.19 & 0.58 & 0.07 \\
\hline Airborne spore density $(\mathrm{CFU} / \mathrm{min})^{\mathrm{b}}$ & ND & A & A & A & A & A & A & A & $\mathrm{L}$ & $\mathrm{H}$ & A & $\mathrm{H}$ & $\mathrm{L}$ & $\mathrm{L}$ & A \\
\hline Leaf spots per trap plant ${ }^{\mathrm{c}}$ & ND & 0 & 0 & 0 & 14.0 & 207.3 & 102.5 & 0.75 & 11.5 & 5.75 & 0 & 0 & 0 & ND & ND \\
\hline Fruit spots per trap plant ${ }^{c}$ & ND & 0 & 0 & 0 & 2 & 1 & 0 & 0.75 & 0 & 0 & 0 & 0 & 0 & ND & ND \\
\hline Days with $\geq 1.0 \mathrm{~mm}$ of rain per week & 1 & 1 & 0 & 2 & 3 & 2 & 3 & 2 & 1 & 1 & 4 & 0 & 2 & 2 & 1 \\
\hline Cumulative rainfall (mm per week) & 14.2 & 13.2 & 0.8 & 7.9 & 26.7 & 71.1 & 101.3 & 21.1 & 24.4 & 3.8 & 41.9 & 0.0 & 81.8 & 0.8 & 5.8 \\
\hline Mean daily maximum temperature (C) & 22.5 & 20.1 & 23.2 & 27.5 & 22.8 & 24.5 & 24.6 & 22.7 & 24.2 & 28.6 & 29.1 & 28.9 & 29.1 & 29.8 & 32.3 \\
\hline
\end{tabular}

${ }^{a}$ Date denotes the end of the weekly exposure period for trap plants, the end of the weekly summary period for weather variables, and the weekly assessment date for disease variables and spore sampling.

b Determined with a six-stage Andersen sampler operated separately for 30 and $60 \mathrm{~s}$ on each sampling date and categorized into four classes based on total number of Exobasidium maculosum CFU obtained in the sampler per minute: sampler: A = absent (0); $\mathrm{L}=$ low (1 to 50), $\mathrm{M}=$ medium (51 to 200), and $\mathrm{H}=$ high $(>200) \mathrm{CFU} / \mathrm{min} . \mathrm{ND}=$ not determined.

${ }^{c}$ Average of four potted trap plants each for monitoring leaf or fruit infection exposed weekly. ND = not determined. 
spot pressure was low in 2017 (likely associated with dry spring weather and damage of susceptible leaf tissue in the mid-March freeze), disease incidence in the treatment plots mirrored the previously collected pathogen population density data, in that shootlevel leaf spot incidence was highest in the dormant oil treatment and lowest in the lime sulfur treatment (Fig. 4). Indeed, there was a significant positive correlation between log-transformed E. maculosum population densities in mid-March (at the mouse ear to shoot elongation growth stage) and shoot-level leaf spot incidence in mid-May (when shoots were fully expanded and hardened off) across the four treatments $(r=0.978, P=0.0221, n=4)$.

\section{Discussion}

This study represents the first investigation of the disease cycle of E. maculosum causing Exobasidium leaf and fruit spot of blueberry in the southeastern United States. Whereas it is often preferable to describe disease cycle components using artificial inoculation trials, previous efforts to reproduce symptoms on rabbiteye blueberry by inoculation with basidiospores or conidia of E. maculosum have proven unsuccessful. To circumvent this constraint, we applied an empirical approach, conducting epidemiological field studies with

Table 3. Contingency table analysis showing numbers of leaves on Premier trap plants with or without symptoms of Exobasidium leaf spot on marked shoot segments $(n=30)$ that were either hardened-off (lower section of the shoot) or tender (upper section of the shoot) in a blueberry planting near Alma, GA in April 2016

\begin{tabular}{lcc}
\hline Shoot segment & Asymptomatic leaves & Symptomatic leaves \\
\hline Tender & 46 & 28 \\
Hardened-off & 166 & 5 \\
\hline a Analysis: $\chi^{2}=51.1, P<0.0001, \mathrm{df}=1$ &
\end{tabular}

Table 4. Contingency table analysis showing numbers of leaf clusters with or without symptoms of Exobasidium leaf spot on Premier trap plants on which different leaf development stages were marked prior to weekly exposure periods in a blueberry planting near Alma, GA in $2016^{\mathrm{a}}$

\begin{tabular}{lcc}
\hline $\begin{array}{l}\text { Leaf development } \\
\text { stage at exposure }\end{array}$ & $\begin{array}{c}\text { Asymptomatic leaf } \\
\text { clusters following } \\
\text { exposure }\end{array}$ & $\begin{array}{c}\text { Symptomatic leaf } \\
\text { clusters following } \\
\text { exposure }\end{array}$ \\
\hline Late green tip & 44 & 3 \\
Mouse ear & 71 & 13 \\
Shoot elongation & 49 & 45 \\
\hline
\end{tabular}

analysis: $\chi^{2}=36.5, P<0.0001, \mathrm{df}=2$.

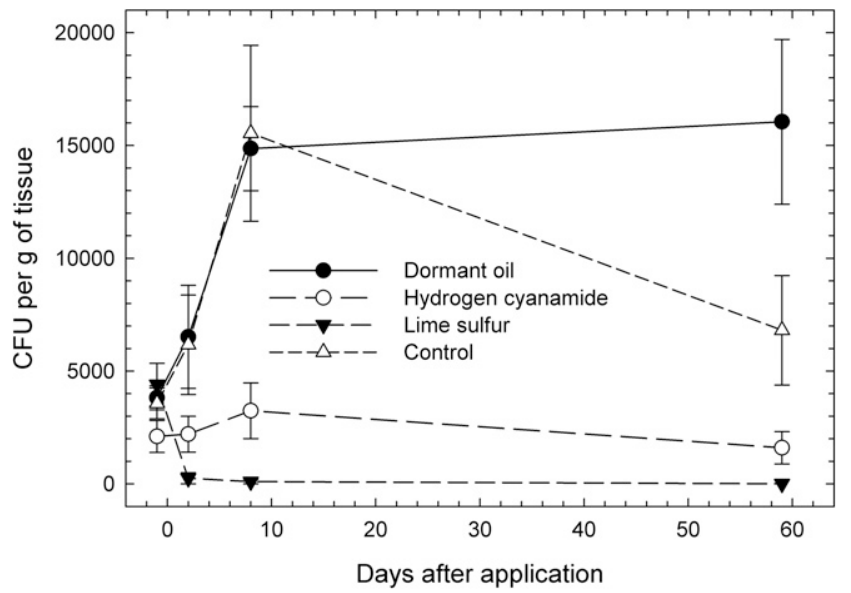

Fig. 3. Epiphytic population densities of Exobasidium maculosum, determined by dilution plating onto semiselective medium, on green bark of field-grown Premier rabbiteye blueberry plants following application of different dormant treatments on 18 January 2017 (day 0). Values are means and standard errors of four replicate plots, each with tissue collected from 10 shoots/plot. natural inoculum to shed light on the means of pathogen overwintering, spore dispersal, seasonal timing of infection, and disease progression by E. maculosum.

Using this approach, we documented epiphytic overwintering of E. maculosum on blueberry tissues during the dormant season through early spring. During those periods, the pathogen was recovered from all plant surfaces tested, although population densities were more variable for some tissue types than for others. We presume that E. maculosum was most likely present on the surface of these tissues as yeast-like conidia, which is generally considered the saprophytic stage of Exobasidium (von Arx et al. 1982). We also showed that a decrease or increase in such surface populations following agrichemical applications during the dormant season was associated with reduced or increased incidence, respectively, of primary infection of leaves in treated field plants later in the spring. Furthermore, spore trapping with the Andersen sampler indicated that airborne basidiospores of E. maculosum were not present in detectable densities within the study area prior to the first appearance of leaf and fruit spots on field plants affected by the disease, thus indicating that primary inoculum is not introduced via airborne spores from potential disease reservoirs outside the field.

Taken together, the most parsimonious explanation for the above observations is that primary infection of emerging leaves and young, green fruit in the spring occurs from overwintered surface inoculum of E. maculosum (presumably yeast-like conidia), either by inoculum splashing or via direct infection from inoculum on infested buds as leaves are emerging and expanding. The latter scenario is less plausible, given that we would not have been able to observe symptoms of primary leaf infection on trap plants simultaneously with those on field plants if primary infection had been due to bud contamination with the pathogen.

Leaf spot progress curves on field plants followed that of a monocyclic disease, as suggested by single peaks for the four leaf spot classes (new, mature, sporulating, and postsporulation). Indeed, during maximum production of basidiospores in the field (high proportion of sporulating lesions on field plants and high spore densities documented with the Andersen sampler), both infection of leaf trap plants and appearance of new leaf spots on field plants were virtually absent. This lack of new leaf infections during peak basidiospore production and dispersal clearly was not due to a lack of susceptible tissue, given that trap plants consistently had appropriate leaf development stages (mouse-ear to early shoot elongation) whenever they were exposed in the field. An alternative explanation is the transition

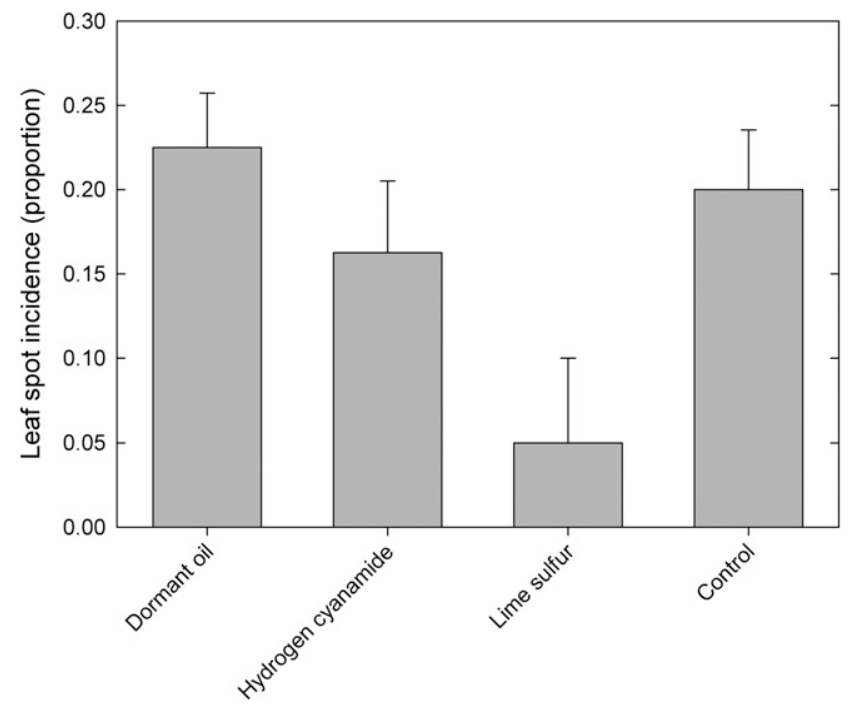

Fig. 4. Shoot-level incidence of Exobasidium leaf spot on current-season shoots of field-grown Premier rabbiteye blueberry plants in mid-May 2017 following application of different dormant treatments on 18 January 2017. Values are means and standard errors of four replicate plots, each with disease assessed on 20 shoots/plot. 
to unfavorable environmental conditions during late April to early May when infection on trap plants and new lesions on field plants dropped off markedly. It is well established that members of the genus Exobasidium are particularly sensitive to high temperatures in culture and in the field (De Weille 1960; Graafland 1960), and physiological studies with isolates of a range of Exobasidium spp. showed that none of the species tested could be cultured at temperatures $>29^{\circ} \mathrm{C}$ (Graafland 1960; Sundstrom 1964). This appears consistent with our field data from 2016, where mean daily maximum temperatures were consistently close to $29^{\circ} \mathrm{C}$ or higher during and after the week ending 6 May, at which time no more infection on trap plants occurred (Table 2). In 2015, however, a different pattern was observed, in that leaf infection of trap plants ceased during the weeks ending 24 April and 1 May despite the prevalence of moderate temperatures (mean daily maximum temperatures of 26.0 and $24.5^{\circ} \mathrm{C}$, respectively) and the occurrence of multiple rainy days during those weeks (Table 1). Thus, unfavorable temperatures alone are insufficient to explain the lack of leaf infection during peak basidiospore dispersal periods of E. maculosum in this study.

With regard to fruit infection, disease progress curves on field plants showed that the first fruit spots can be observed on small, green fruit within 1 to 3 weeks of petal fall (requiring removal of the waxy layer to visualize these early spots). The infections causing these symptoms would have had to occur around petal fall, before the presence of sporulating leaf spots in the field and before airborne propagules of E. maculosum were detected with the Andersen sampler. The most parsimonious explanation for these observations is that the same primary inoculum causing leaf infections also causes early fruit infections. This is supported by the fruit trap plant study in 2016, where plants forced in the greenhouse to have small, green fruit during field exposure were infected at the same time as leaf trap plants having susceptible leaf stages. Subsequent disease progression on fruit on field plants is more difficult to explain, in part because of variability in fruit disease incidence over time associated with abscission of some of the affected fruit. The delayed peak in fruit spot incidence compared with leaf spot incidence could be due to a longer incubation period on fruit or a delayed primary infection period on fruit versus leaves associated with the hardening-off (and decreased susceptibility) of leaf tissue as susceptible young green fruit become available in the field. Alternatively, it may be possible that basidiospores produced on leaves cause some of the later infections on fruit, given the temporal overlap among sporulating leaf lesions, E. maculosum airborne propagule dissemination as documented with the Andersen sampler, and the emergence of fruit spots in the field. However, this is not supported by the trap plant study, where no fruit infections were observed during the basidiospore dissemination period. Hence, only successful artificial inoculation trials where basidiospores are used to infect young, still-green fruit will provide conclusive evidence as to whether or not basidiospores produced on leaves are capable of infecting fruit during the same season.

Based on the above considerations, the role of basidiospores in this pathosystem appears to be less one of contributing to reinfection during the same growing season and more one of enabling sexual recombination and serving as dispersal agents until infection occurs again at the beginning of the next growing season. Basidiospores of Exobasidium spp., in general, are hyaline, and exposure to UV radiation and temperatures in excess of $29^{\circ} \mathrm{C}$ are fatal to most species (De Weille 1960; Graafland 1960; Sundstrom 1964; Visser et al. 1961); hence, oversummering and subsequent overwintering of the pathogen as basidiospores is highly unlikely. Instead, it is more plausible that the yeast-like conidia are serving this function. When basidiospores of E. maculosum are released onto culture media, they readily bud to produce yeast colonies. Although the longevity of the conidia of E. maculosum has not been investigated, inoculation experiments using monospore cultures of conidia of the related E. japonicum on dormant azalea buds showed that the pathogen remained capable of producing symptoms for up to 6 months after inoculation (Graafland 1960); however, it was not clear whether the pathogen remained an epiphyte during that period, causing infection when the buds broke, or whether the bud scales were infected latently following inoculation, with symptoms only becoming apparent during bud break 6 months later. This led Graafland (1960) to hypothesize that the pathogen was capable of persisting on buds or within budscales until such time as new infections could occur at bud break and leaf development. For E. maculosum, our tissue-plating studies documented that the pathogen is consistently present on the surface of blueberry plants during the dormant season, thereby providing strong evidence that this species is capable of effective epiphytic survival.

A review of the literature suggests that one common feature among diseases caused by Exobasidium spp. is that only young, tender host tissues are susceptible to infection (De Weille 1960; Graafland 1960; Hilborn and Hyland 1956; Nickerson and Vander Kloet 1997; Sundstrom 1964; Wolf and Wolf 1952). This was confirmed in the present study for leaf and fruit infection by E. maculosum. In other aspects of pathogenesis and epidemiology, the genus Exobasidium appears to be highly variable. The type of infection produced ranges from localized spots or blisters (such as with E. maculosum and E. vexans) to locally systemic galling (e.g., E. japonicum) and fully systemic infection (such as with the Exobasidium sp. causing red leaf of lowbush blueberry) (Nannfeldt 1981). Variability is also observed among species in the roles played by the different spore types. The majority of Exobasidium spp. produce both basidiospores and conidia and, in all cases where artificial inoculation has been successful with those species, both spore types are capable of infecting (Graafland 1960; Sundstrom 1964). E. vexans represents an anomaly in that this species only produces basidiospores and appears to have lost its saprophytic stage. The near opposite appears to be the case for E. maculosum, where the saprophytic stage dominates the annual disease cycle and the basidiospores may primarily serve the purpose of dispersal (along with increasing genetic variability), with limited or no contribution to the within-season epidemic. This latter life strategy is very similar to that of ascomycetes within the genus Taphrina (e.g., Taphrina deformans (Berk.) Tul. causing peach leaf curl), where the sexual spores are released during a brief period in the spring to produce yeast-like conidia, which-following epiphytic oversummering and overwintering - incite a single cycle of primary infection the following spring (Mix 1935). The striking similarity in general life history strategies between Exobasidium and Taphrina spp. was noted more than 150 years ago by Woronin (1867) when he erected the genus Exobasidium, and has been reiterated by Graafland (1960) and von Arx et al. (1982) in their reviews of the genus. These two fungal groups may also share other similar epidemiological characteristics, in that infection only occurs under narrowly specific environmental conditions of temperature, humidity, rainfall, and plant phenology (De Weille 1960; Graafland 1960; Rossi et al. 2006).

Exobasidium leaf and fruit spot of blueberry in the southeastern United States can be controlled remarkably well with a single latedormant application of liquid lime sulfur (Brannen et al. 2017). Our results, documenting the importance of epiphytic primary inoculum and the monocyclic nature of disease progression (at least on leaves), provide a biological foundation for this empirically derived disease management tactic. Our results also suggest that there may be potential to manipulate other cultural, horticultural, or pest management practices during the epiphytic survival phase of the pathogen to further mitigate the impacts of the disease (Scherm et al. 2017). In the context of optimizing disease management, additional research is also needed to quantify the contribution of basidiospores to fruit infection, which will require development of artificial inoculation protocols for this pathosystem where efforts to accomplish artificial inoculation have been unsuccessful to date.

\section{Acknowledgments}

We thank P. Brannen, M. Brewer, F. Martin, R. Allen, and collaborating blueberry producers for their support.

\section{Literature Cited}

Brannen, P., Scherm, H., and Allen, R. M. 2017. Management of Exobasidium leaf and fruit spot disease of blueberry. Acta Hortic. 1180:215-220. 
Brannen, P., Scherm, H., Cline, B., and Ingram, D. 2011. Exobasidium fruit and leaf spot: An emerging concern on blueberries in the Southeast. Small Fruit News 11:1-3.

Brewer, M. T., Turner, A. N., Brannen, P. M., Cline, W. O., and Richardson, E. A. 2014. Exobasidium maculosum, a new species causing leaf and fruit spots on blueberry in the southeastern USA, and its relationship with other Exobasidium spp. parasitic to blueberry and cranberry. Mycologia 106: 415-423.

Burrack, H., ed. 2013. 2013 Southeast Regional Blueberry Integrated Management Guide. Bull. 48. College of Agricultural and Environmental Sciences, University of Georgia, Athens.

Cline, W. O. 1998. An Exobasidium disease of fruit and leaves of highbush blueberry. Plant Dis. 82:1064.

Cline, W. O., and Brewer, M. T. 2017. Exobasidium leaf and fruit spot. Pages 22-23 in: Compendium of Blueberry, Cranberry, and Ligonberry Diseases and Pests, 2nd ed. J. J. Polashock, F. L. Caruso, A. L. Averill, and A. C. Schilder, eds. American Phytopathological Society Press, St. Paul, MN, U.S.A.

Collins, J. 2017. Worst Southeast freeze in 10 years wipes out blueberry and peach crops. USA Today, 21 March 2017.

De Weille, G. A. 1960. Blister blight (Exobasidium vexans) in tea and its relationship with environmental conditions. Neth. J. Agric. Sci. 8:183-210.

Gadd, C. H., and Loos, C. A. 1948. The fungus Exobasidium vexans. Tea Q. 20: 54-61.

Graafland, W. 1960. The parasitism of Exobasidium japonicum Shir. on azalea. Acta Bot. Neerl. 9:347-379.

Hilborn, M. T., and Hyland, F. 1956. The mode of infection of lowbush blueberry by Exobasidium vaccinii. (Abstr.). Phytopathology 46:241.

Ingram, R. J. 2018. Symptomology, epidemiology, and real-time PCR-based detection of Exobasidium leaf and fruit spot of blueberry caused by Exobasidium maculosum. Ph.D. dissertation, Department of Plant Pathology, University of Georgia, Athens.

Ingram, R. J., Allen, R. M., and Scherm, H. 2017. Symptomology and epidemiology of Exobasidium leaf and fruit spot of blueberry. Acta Hortic. 1180:205-214.

Mims, C. W., and Nickerson, N. L. 1986. Ultrastructure of the host-pathogen relationship in red leaf disease of lowbush blueberry caused by the fungus Exobasidium vaccinii. Can. J. Bot. 64:1338-1343.
Mix, A. J. 1935. The life history of Taphrina deformans. Phytopathology 25:41-66. Nannfeldt, J. A. 1981. Exobasidium, a taxonomic reassessment applied to the European species. Symb. Bot. Ups. 23:1-72.

NeSmith, D. S., Krewer, G., and Williamson, J. G. 1998. A leaf bud development scale for rabbiteye blueberry (Vaccinium ashei Reade). HortScience 33:757.

Nickerson, N. L., and Hildebrand, P. D. 2017. Red leaf. Pages 53-54 in: Compendium of Blueberry, Cranberry, and Ligonberry Diseases and Pests, 2nd ed. J. J. Polashock, F. L. Caruso, A. L. Averill, and A. C. Schilder, eds. American Phytopathological Society Press, St. Paul, MN, U.S.A.

Nickerson, N. L., and MacNeill, N. H. 1987. Studies on the spread of red leaf disease, caused by Exobasidium vaccinii, in lowbush blueberries. Can. J. Plant Pathol. 9:307-310.

Nickerson, N. L., and Vander Kloet, S. P. 1997. Exobasidium leaf spot of lowbush blueberry. Can. J. Plant Pathol. 19:66-68.

Rossi, V., Bolognesi, M., Languasco, L., and Giosque, S. 2006. Influence of environmental conditions on infection of peach shoots by Taphrina deformans. Phytopathology 96:155-163.

Scherm, H., Allen, R., and Brannen, P. M. 2017. Dormant oil and hydrogen cyanamide impact development of Exobasidium leaf and fruit spot of blueberry. Dixie Blueberry News 17:6-9.

Stewart, J. E., Brooks, K., Brannen, P. M., Cline, W. O., and Brewer, M. T. 2015. Elevated genetic diversity in the emerging blueberry pathogen Exobasidium maculosum. PLoS ONE 10:e0132545. https://doi.org/10.1371/journal.pone. 0132545

Sundstrom, K. R. 1964. Studies of the physiology, morphology and serology of Exobasidium. Symb. Bot. Ups. 18:1-89.

Visser, T., Shanmuganathan, N., and Sabanayagam, J. V. 1961. The influence of sunshine and rain on tea blister blight, Exobasidium vexans Massee, in Ceylon. Ann. Appl. Biol. 49:306-315.

von Arx, J. A., van der Walt, J. P., and Liebenberg, N. V. D. M. 1982. The classification of Taphrina and other fungi with yeast-like cultural states. Mycologia 74:285-296.

Wolf, F. T., and Wolf, F. A. 1952. Pathology of Camellia leaves infected by Exobasidium camelliae var. gracilis Shirai. Phytopathology 42:147-149.

Woronin, M. S. 1867. Exobasidium vaccinii. Ber. Verh. Natforsch. Ges. Freibg. Breisgau. 4:397-416. 